\title{
The American
}

Political Science Review

\section{VOLUME XXIX}




\title{
The American \\ Political Science Review
}

\author{
BOARD OF EDITORS
}

William Anderson,

University of Minnesota

Robert C. Brooks, Swarthmore College

Francis W. Coker, Yale University

Robert E. Cushman, Cornell University

Waiter F. Dodd, Chicago, Illinois
Charles G. Haines, University of California (L.A.)

Arthur N. Holcombe,

Harvard University

Kirk H. Porter,

Iowa State University

Thomas H. Reed,

University of Michigan

Leonard D. White,

Washington, D.C.

Fraderic A. Oga, Managing Editor, University of Wisconsin

\section{VOLUME XXIX}

1935

\section{GEORGE BANTA PUBLISHING COMPANY \\ MENASHA, WISCONSIN}

1935

Reprinted with the permission of the American Political Science 1ssociation JOHNSON REPRINT CORPORATION JOHNSON REPRINT COMPANY LTD. 111 Fifth Avenue, New York, N.Y. 10003 Berkeley Square House, London, W.1. 
First reprinting, 1969, Johnson Reprint Corporation Printed in the United States of America 


\section{CONTENTS}

NUMBER 1-February, 1935

Democracy in Transition, Walter $J$. Shepard .................

Politics, Personalities, and the Federal Trade Commission, II, E. Pendleton

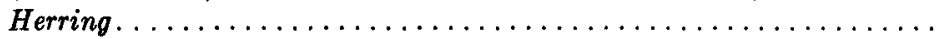

Constitutional Law in $1933-34$, Robert $E$. Cushman . . . . . . . . .

American Government and Politics

National Parties and Local Politics, Ellen Deborah Ellis............

Organization of the Executive Branch of the National Government of the United States. L. F. Schmeckebier.................

Legislative Notes and Reviews

Nebraska Provides for a One-House Legislature, John P. Senning . . . . .

Legislative Recording in the United States, Phillips Bradley........

Foreign Governments and Politics

Constitutional Reform in France, Robert $K$. Gooch . . . . . . . . .

The Hitler Referenda, Arnold J. Zurcher. . . . . . . . . . . . .

News and Notes, Personal and Miscellaneous, Managing Editor.........

Thirtieth Annual Meeting of the American Political Science Association.

Report of the Committee on Policy for the Year, 1934, Thomas H. Reed...

Book Reviews and Notices. . . . . . . . . . . . . . . . . . . . .

Recent Publications of Political Interest

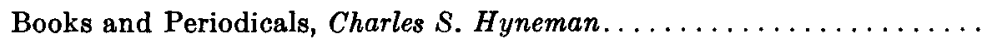

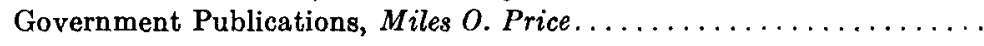

NUMBER 2-APriL, 1935

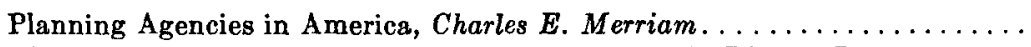
The Classification of International Organizations, I, Pitman B. Potter..... American Government and Politics

National Stamp-Tax Laws and State Instrumentalities, Alden L. Powell.

Executive Orders-A Bibliographical Note, Everett $S$. Brown........

Gover: vr Pinchot and the Late Magistrate Stubbs, John T. Salter.....

Pulis idministration

The Nex Amateur in Public Administration, Paul T. Stafford........

Coördination. \& National Administration, S. Lyle Post............ International Affairs

The Saar Plebiscite, James $K$. Pollock..................

News and Notes, Per onal and Miscellaneous, Managing Editor.........

The Encyclopecia of the Social Sciences, John A. Fairlie..........

Book Roviews and Notices. . . . . . . . . . . . . . . . . . .

Recent Publications of Political Interest

Books and Periodicals, Charles $\boldsymbol{S}$. Hyneman. . . . . . . . . . . .

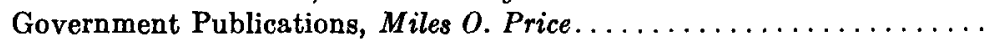

Number 3-June, 1935

The Legal Monism of Alfred Verdross, Henry Janzen. . . . . . . . . . . The Classification of International Organizations, II, Pitman B. Potter.... American Government and Politics

The Gubernatorial Controversy in North Dakota, Roy L. Miller...... State Constitutional Development through Amendment, 1934, Wilson

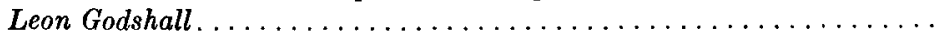

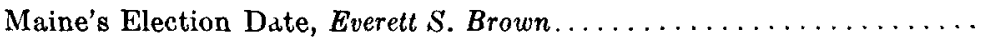


Public Administration

Public Administration in the United States in 1934, John M. Gaus and

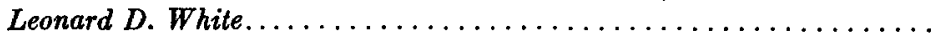

Comparative Civil Service Statistics: Germany, Fritz Morstein Marx... Judicial Affairs

The Work of Judicial Councils, Pressly S. Sikes. . . . . . . . . . . . .

A New Method of Selecting Judges in California, Charles Aikin......

Foreign Governments and Politics

The Position of the English Monarchy Today, E. P. Chase........

International Affairs

The Japanese Mandate Naval Base Question, Luther H. Evans. . . . . .

News and Notes, Personal and Miscellaneous, Managing Editor. . . . . . . .

Book Reviews and Notices. . . . . . . . . . . . . . . . . . . . . . .

Recent Publications of Political Interest

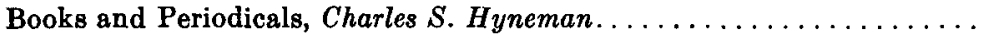

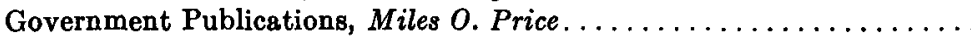

NUMBer 4-AUgust, 1935

Autocracy Versus Democracy in Contemporary Europe, I, Karl Loewenstein. National Socialist Conceptions of International Law, Lawrence Preuss..... State Constitutional Law in 1934-35, Charles G. Haines............... American Government and Politics

Organization of the Executive Branch of the National Government of the

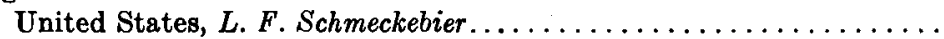
Achievements of the Kansas Legislative Council, Frederick H. Guild... Municipal Notes, William Anderson (ed.)

Cities and the National Government under the New Deal, C. C. Ludwig. Training Municipal Officials, Albert $H$. Hall............... Municipal Government in National Socialist Germany, Roger H. Wells. Local Government in Italy under Fascism, Carlo Rossi..............

News and Notes, Personal and Miscellaneous, Managing Editor. . ........ Book Reviews and Notices. . . . . . . . . . . . . . . . . . . . . . Doctoral Dissertations in Political Science, Grayson L. Kirk........... Recent Publications of Political Interest

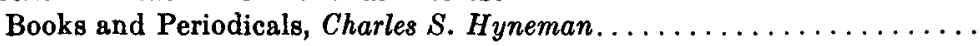
Government Publications, Miles 0 . Price.................

Autocracy Versus Democracy in Contemporary Europe, II, Karl Loewen-

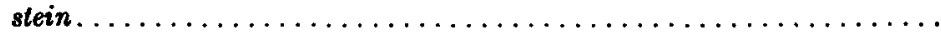

Recent Developments in Political Geography, I, Richard Hartshorne. . . . . . Roosevelt's Latin-American Policy, John M. Mathews............... American Government and Politics

Fascism in America?, $\boldsymbol{H}$. Arthur Steiner . . . . . . . . . . . . . The "Patent" Way to Balance the National Budget, Forrest $R$. Black. . The Contributions of Samuel J. Randall to the Rules of the National House of Representatives, Albert V. House, Jr.............

Public Administration

Development of National Administration in the United States, 1932-35,

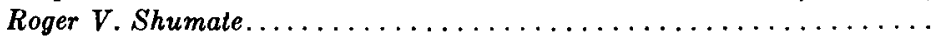
Organization of the Executive Branch of the National Government of the

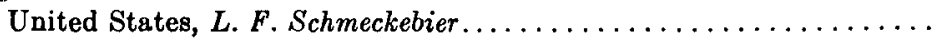


Foreign Governments and Politics

The Five Hundredth Anniversary of the Swedish Riksdag, Eric C. Bell-

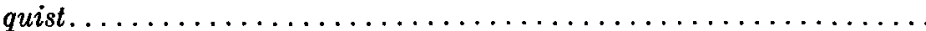

International Affairs

Is the International Labor Organization Autonomous?, Paul G. Stein-

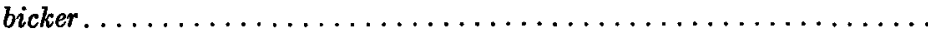
Appointment of Ameriean Delegates to the International Labor Organi-

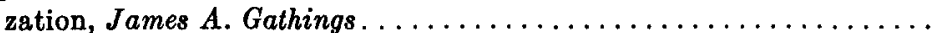

News and Notes, Personal and Miscellaneous, Managing Editor......... The Social Science Research Council's Committee on Public Administra-

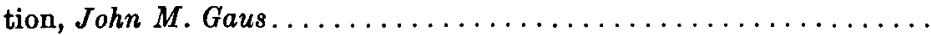

Book Reviews and Notices. . . . . . . . . . . . . . . . . . . .

Recent Publications of Political Interest

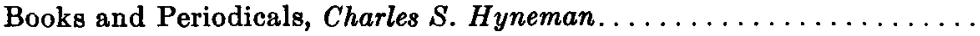

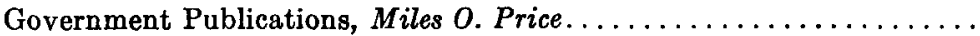

\section{NUMBER 6-December, 1935}

Recent Developments in Political Geography, II, Richard Hartshorne. . . . . An Analysis of the 1932 Presidential Vote in Chicago, Harold F. Gosnell and Norman N. Gill.

American Government and Politics

First Session of the Seventy-fourth Congress, $E$. Pendleton Herring . . .

The Ratification of the Twenty-first Amendment, Everett S. Brown... .

Organization of the Executive Branch of the National Government of the

United States, L. F. Schmeckebier.

International Affairs

Current Neutrality Problems-Some Precedents, an Appraisal, and a

Draft Statute, Phillips Bradley.

News and Notes, Personal and Miscellaneous, Managing Editor........ 1042

Book Reviews and Notices. . . . . . . . . . . . . . . . . . . . 1048

Recent Publications of Political Interest

Books and Periodicals, Charles S. Hyneman................ 1098

Government Publications, Miles O. Price................. 1124

Index to Volume XXIX, Mary C. Trackett................ 1129 